\title{
Effects of the Physiological Age of Bananas on Their Susceptibility to Wound Anthracnose Due to Colletotrichum musae
}

\author{
M. Chillet, O. Hubert, M. J. Rives, and L. de Lapeyre de Bellaire, CIRAD FLHOR, Laboratoires de Physiologie \\ et de Pathologie Végétale, Station de Neufchâteau, Sainte-Marie, 97130 Capesterre Belle-Eau, Guadeloupe (FWI)
}

\begin{abstract}
Chillet, M., Hubert, O., Rives, M. J., and de Lapeyre de Bellaire, L. 2006. Effects of the physiological age of bananas on their susceptibility to wound anthracnose due to Colletotrichum musae. Plant Dis. 90:1181-1185.

Wound anthracnose, caused by Colletotrichum musae, and early ripening are the main problems affecting the quality of export bananas (Musa AAA Cavendish) from the Caribbean. These problems generally concern bananas grown in lowland plantations during the rainy season. Three experiments were carried out to study the influence of the physiological age of bananas, calculated on the basis of mean daily temperature sums, on their susceptibility to anthracnose. Stressful growing conditions, especially soil flooding, slowed fruit growth but had no direct effect on fruit susceptibility to C. musae or on the green life. However, fruit that had accumulated lower temperature sums were less susceptible to wound anthracnose. By varying the source-sink ratio, we show that bananas of the same grade but different physiological ages had markedly different susceptibility to C. musae. Bananas with the same temperature sum accumulation but grown in different soil-climate conditions had different levels of susceptibility. Fruit grown in cooler, highland areas were less susceptible to $C$. musae than fruit of the same physiological age from lowland plantations. Our results suggest that temperature sum accumulation rate is a critical factor affecting the susceptibility of bananas to the pathogen.
\end{abstract}

Additional keywords: postharvest disease, wound disease

Wound anthracnose and early ripening of fruit are serious problems that decrease the quality of export bananas (Musa AAA Cavendish) from the West Indies (16). Anthracnose is caused by the fungus $\mathrm{Col}$ letotrichum musae, which spreads from the floral parts and senescent bracts to contaminate fruit in plantations (9). Conidia reach the fruit surface in runoff rainwater on the banana bunch (8). They quickly germinate and form melanized appressoria, which are quiescent structures of the pathogen (28). These appressoria germinate during fruit maturation and form infection hyphae that colonize the peel and then penetrate into the fruit pulp (37). When fruits are wounded, rot develops long before the fruit ripens, and lesions expand quickly (26). This form of the disease, called wound anthracnose, can trigger early fruit ripening, sometimes seriously damaging fruit when it develops during container transport (29).

Early ripening of fruit can be due to physiological factors independent of postharvest disease development. Banana is a

\section{Corresponding author: M. Chillet}

E-mail: chillet@cirad.fr

Accepted for publication 5 April 2006.

DOI: 10.1094/PD-90-1181

(C) 2006 The American Phytopathological Society climacteric fruit, but must be harvested green and remain in a preclimacteric phase until reaching the ripening room, where it undergoes an ethylene treatment to induce ripening. Harvesting fruit too late will reduce the length of the preclimacteric phase, which is also called the green life (30). Moreover, harvesting physiologically old fruit can induce ripening of all boxed bananas in a container due to the triggering effect of ethylene release by such bananas on maturation (25).

These qualitative problems generally arise during the hot rainy season and especially affect fruit growing in lowland plantations. Previous studies revealed that bananas grown in lowland areas are more susceptible to wound anthracnose than those grown in highland zones (4). These susceptible bananas were from banana plants with high foliar Mn concentration, a feature that is typical of plants grown under stressful conditions, e.g., in poorly drained plots and/or under anoxic soil conditions (10). Moreover, such bananas produce more ethylene in response to wounding than highland-grown bananas, especially during the rainy season (3). In these studies, however, only commercial grade diameter bananas were harvested without consideration of their physiological age. This fruit grade-oriented harvesting method is adopted by most banana growers. However, basing a harvesting strategy solely on this criterion overlooks the physiological age of the fruit, i.e., a development stage calculated as the temperature sum accumulated by the fruit (using $14^{\circ} \mathrm{C}$ as the base temperature). Ganry (13) showed that commercial grade bananas have accumulated approximately 900 degree-days (dd) under normal growth conditions in Guadeloupe (FWI). It has also been demonstrated that banana growth rates are dependent on growing conditions $(6,21)$. For example, fruit growth rate differs according to the source-sink ratio. In addition, the flowering-to-harvest time and the temperature sum accumulated by the fruit can differ substantially between bananas of the same commercial grade. The physiological ages of bananas harvested at the same commercial grade can thus vary markedly. Hence, it is possible that the high anthracnose susceptibility of lowland bananas during the rainy season occurs when they are harvested at an older physiological age. Fruit from stressed banana plants could also be more susceptible to anthracnose due to the plant's physiological responses to adverse conditions, such as a slowdown in growth (21).

We examined the relationship between the physiological age of the fruit and the susceptibility to wound anthracnose induced by $C$. musae. Three experiments were conducted to analyze: (i) the effects of flooding, a stressful growing condition, on bananas harvested at the same physiological age, (ii) the effects on fruit quality of early harvesting of bananas from two distinctly different soil-climate zones, and (iii) the effects of modifying the source-sink ratio on bananas harvested at a constant commercial grade and physiological age.

\section{MATERIALS AND METHODS}

Plant material. All experiments were conducted in Guadeloupe (French West Indies: $16^{\circ} \mathrm{N}, 62^{\circ} \mathrm{W}$ ) with Musa acuminata (AAA, cv. Grande Naine, Cavendish subgroup). Micropropagated banana plants in their first growth cycle were planted in a greenhouse to test for effects of flooding or in the field for the source-sink ratio test. For the test of age and susceptibility, banana plants grown in two locations were in their third growth cycle.

Experimental design. To test the effects of flooding on banana susceptibility to $C$. musae, 27 banana plants were grown in a greenhouse (30 m length, $8 \mathrm{~m}$ width, 6 $\mathrm{m}$ high, temperature between 25 and $31^{\circ} \mathrm{C}$ ) in individual pots (1.2 $\mathrm{m}$ high, $1 \mathrm{~m}$ diame- 
ter) filled with $1 \mathrm{~m}^{3}$ of alluvial soil. The plants were fertilized weekly $\left(17 \mathrm{~g} \mathrm{KNO}_{3}\right.$ and $4 \mathrm{~g}$ urea per plant), and irrigation was controlled by measurement of the water status in the soil every day (water potential measured at $30 \mathrm{~cm}$ depth with tensiometers [SMS 2500 S (sensor) and SMS 2000 (tube)] and RedOx potential measured with RedOx probe [Eijkelkamp probe Paltin International Inc. (USA)]). Nine replications of each of two stress treatments and one control treatment were placed arbitrarily in the greenhouse. In treatment 1 (9 banana plants), pot drainage was stopped at the flowering stage, about 6 months after planting, and watering was continued until soil saturation; soil water potential ranged from $-2 \mathrm{kPa}$ to $0 \mathrm{kPa}$, and RedOx potential was around $-300 \mathrm{mV}$. In treatment 2 (9 banana plants), pot drainage was stopped 3 months after planting, and watering was continued until soil saturation as above; soil water potential ranged from $-2 \mathrm{kPa}$ to $0 \mathrm{kPa}$, and RedOx potential was around $-300 \mathrm{mV}$. In the control (9 banana plants), irrigation was regulated so that the banana plants would not be under water deficit; the soil water potential ranged from -10 to $-20 \mathrm{kPa}$, and the $\mathrm{Re}$ dOx potential was above $200 \mathrm{mV}$. Bunches were harvested when the temperature sum reached $900 \mathrm{dd}$.

To test the effects of harvesting bananas at an early physiological age on susceptibility to $C$. musae, 20 banana plants at the flowering stage within each of two contrasting soil-climate conditions, named lowland plain zone (altitude: $50 \mathrm{~m}$, halloysitic soil [11], mean daily temperature during experiment: $25.5^{\circ} \mathrm{C}\left[\max : 29^{\circ} \mathrm{C}\right.$, min: $\left.22^{\circ} \mathrm{C}\right]$ ) and highland mountain zone (altitude: $700 \mathrm{~m}$, soil classified as Umbric Andosol [11], mean daily temperature during experiment: $21.5^{\circ} \mathrm{C}$ [max: $25^{\circ} \mathrm{C}$, min: $\left.19^{\circ} \mathrm{C}\right]$ ), were chosen on the basis of homogeneity in plant size and number of hands per bunch. The plants were separated ran- domly into two groups based on a temperature sum of 700 dd during the flowering-toharvest period (early harvest) and of $900 \mathrm{dd}$ during the flowering-to-harvest period (standard harvest) (14). Thus, there were 10 plants for each treatment. This experiment was repeated three times, in May 2002, December 2003, and June 2004 (harvest date), with the same number of plants and the same number of repetitions.

The effects of the source-sink ratio on banana susceptibility to $C$. musae were tested on plants grown in the lowland zone (altitude: $30 \mathrm{~m}$, soil classified as Ferral sol [11], mean daily temperature: $25.5^{\circ} \mathrm{C}$ [max: $29^{\circ} \mathrm{C}$, min: $\left.22^{\circ} \mathrm{C}\right]$ ). Sixty homogeneous banana plants at the flowering stage were chosen for each replication of the experiment. These plants were divided arbitrarily into three treatments. The first one was a "High source-sink ratio treatment" (14 leaves and 2 hands per bunch). At the flowering stage, six of the eight hands on the bunches of 20 plants were trimmed so that only hands II and III (second and third hand from the top of the bunch) remained on the floral stalk. The second treatment was a "Low source-sink ratio treatment" (3 leaves, 8 hands on the bunch). At the flowering stage, 20 banana plants were severely defoliated so that only the three youngest leaves remained. The control was a "Normal source-sink ratio treatment" (14 leaves and 8 hands per bunch) without bunch trimming or defoliation performed on the final 20 banana plants. Two harvest techniques have been practiced in this experiment, the first one based on temperature sum ( $900 \mathrm{dd})$ and the second one on fruit diameter on the third hand reach $(34 \mathrm{~mm})$. Thus, there are 10 plants for each treatment. This experiment was repeated three times, in July 2002, January 2004, and October 2004 (harvest date).

Fruit inoculation. Suspensions of conidia (Colletotrichum musae/strain 46-12 from Guadeloupe [7], stored as frozen conidial suspensions at $-80^{\circ} \mathrm{C}$ in $30 \%$ glycerin) were prepared from 7- to 10-dayold cultures grown on modified Mathur's medium (35). The cultures were maintained at $25^{\circ} \mathrm{C}$ in the dark. Conidia were recovered by washing the cultures with sterile distilled water. The conidial suspensions were filtered through a $10-\mu \mathrm{m}$ sieve to eliminate mycelial fragments. In order to eliminate germination inhibitors contained in the conidial matrix (27), three successive 10-min washings were carried out by centrifugation at 4,000 rpm (JOUAN M 1400, Saint Nazaire, France).

At the flowering stage (horizontal finger stage), two bananas in hand III were inoculated according to the technique described by Chillet and de Lapeyre de Bellaire (2) with $25-\mu$ droplet of a conidial suspension $\left(10^{6}\right.$ conidia per $\left.\mathrm{ml}\right)$. Then, bunches were enclosed in blue plastic covers by the technique commonly implemented in commercial plantations to improve fruit growth by elevating temperature around the bunch and to limit damage caused by thrips (1).

Calculation of fruit age. Temperature probes (Tiny Tag Ultra - Gemini Data Loggers UK Ltd.) were placed under a meteorological shelter on the experimental plots and in the greenhouse. Mean daily temperature was calculated on the basis of hourly temperatures. The physiological age of the fruit (expressed in dd) was calculated by the mean daily temperature sums accumulated by fruit at the $14^{\circ} \mathrm{C}$ threshold during the flowering-to-harvest period (14).

Fruit harvest. Table 1 presents the harvest criteria considered for the different treatments in the three types of experiment. Bananas of hand III on each experimental bunch were separated at harvest.

Physiological characteristics of fruits. Fruit length and diameter were measured on a median finger in the outer row of hand III (18). The green life of bananas in each experimental hand was

Table 1. Locations, treatments, and design of the experiments conducted

\begin{tabular}{|c|c|c|c|c|c|c|}
\hline Growth cycle & Location & Exp. $^{\mathrm{z}}$ & Treatment & $\begin{array}{l}\text { No. of plants } \\
\text { per replicate }\end{array}$ & $\begin{array}{l}\text { No. of } \\
\text { replicates }\end{array}$ & Harvest criteria \\
\hline 1 st & Greenhouse & 1 & $\begin{array}{l}\text { Control } \\
\text { Flooding at flowering } \\
\text { Flooding after } 3.5 \text { months }\end{array}$ & $\begin{array}{l}9 \\
9 \\
9\end{array}$ & 1 & $\begin{array}{l}\mathrm{TS}=900 \mathrm{dd} \\
\mathrm{TS}=900 \mathrm{dd} \\
\mathrm{TS}=900 \mathrm{dd}\end{array}$ \\
\hline $3 \mathrm{rd}$ & $\begin{array}{l}\text { Changy (lowland) } \\
\text { Matouba (highland) }\end{array}$ & 2 & $\begin{array}{l}\text { Lowland early } \\
\text { Lowland standard } \\
\text { Highland early } \\
\text { Highland standard }\end{array}$ & $\begin{array}{l}10 \\
10 \\
10 \\
10\end{array}$ & 3 & $\begin{array}{l}\text { TS }=700 \mathrm{dd} \\
\text { TS }=900 \mathrm{dd} \\
\text { TS }=700 \mathrm{dd} \\
\text { TS }=900 \mathrm{dd}\end{array}$ \\
\hline 1 st & Douville & 3 & $\begin{array}{l}\text { High So/Si, (TS) } \\
\text { High So/Si, (diameter) } \\
\text { Low So/Si, (TS) } \\
\text { Low So/Si, (diameter) } \\
\text { Control, (TS) } \\
\text { Control, (diameter) }\end{array}$ & $\begin{array}{l}10 \\
10 \\
10 \\
10 \\
10 \\
10\end{array}$ & 3 & $\begin{array}{l}\text { TS }=900 \mathrm{dd} \\
\text { Fruit diameter }=34 \mathrm{~mm} \\
\mathrm{TS}=900 \mathrm{dd} \\
\text { Fruit diameter }=34 \mathrm{~mm} \\
\mathrm{TS}=900 \mathrm{dd} \\
\text { Fruit diameter }=34 \mathrm{~mm}\end{array}$ \\
\hline
\end{tabular}

\footnotetext{
${ }^{\mathrm{z}}$ Exp. 1: Effect of flooding on banana susceptibility to Colletotrichum musae / Banana plants in their first cycle of growth have been planted in a greenhouse in individuals pots / Harvest at 900 degree-days (dd). Exp. 2: Effect of harvesting bananas at an early physiological age on susceptibility to C. musae / Two harvest stages (700 and $900 \mathrm{dd}$ ) / Two locations (lowland and highland); Exp. 3: Effect of the source-sink ratio (So/Si) on banana susceptibility to C. musae / High So/Si corresponds to the treatment with 14 leaves functional and only 2 hands per bunch / Low So/Si corresponds to the treatment with 3 leaves and 8 hands per bunch / Control correspond to the treatment with 14 leaves and 8 hands per bunch / Harvest at 900 dd and when fruit diameter reaches 34 mm. $\mathrm{TS}=$ mean daily temperature sum at the $14^{\circ} \mathrm{C}$ threshold.
} 
determined at $20^{\circ} \mathrm{C}$ using the method described by Chillet and de Lapeyre de Bellaire (2). This analysis was performed on a banana cut from the inner row of each hand, after a treatment with a postharvest fungicide (thiabendazole $500 \mathrm{ppm}$ ).

Characterization of fruit susceptibility to $C$. musae. Bananas inoculated at flowering were wounded at harvest using a TA-XT2 penetrometer (SMS) (bruising by calibrated compression of $15 \%$ of the fruit diameter) and stored at $13.5^{\circ} \mathrm{C}$ for 10 days to simulate maritime transport conditions, then stored for a further 10 days at $20^{\circ} \mathrm{C}$ to allow natural ripening.

The length (L) and width (w) of the necrotic tissue was measured after the storage period. The rotted area was then calculated by the ellipse area formula (Length $x$ width $\times \Pi / 4)$. Thus, for each bunch, there are two measurements (because of 2 inoculated fruits). Data were averaged to obtain a single value per bunch.

Statistical analysis. Data were subjected to analysis of variance and means separated by the Newman-Keuls test (at the $5 \%$ probability level). These statistical analyses were performed for each separate experiment using the STAT-ITCF software package.

\section{RESULTS}

Effects of growing conditions on banana susceptibility to $C$. musae. Flooding at the flowering stage or at the vegetative stage had a very clear effect on fruit diameter and length (Table 2). At morphological stage 900 dd (70 days), the mean diameter of flooded bananas was 3 or 4 $\mathrm{mm}$ less than the control, a reduction of
$10 \%$. The mean difference between length of the control bananas and of the most stressed bananas ("Stress after 3.5 months") was $4.2 \mathrm{~cm}$. Flooded conditions therefore caused an overall decrease in fruit length of about $30 \%$.

Although flooding had a major impact on fruit morphology, it had no detectable effects on fruit susceptibility to $C$. musae or on the green life.

Effects of harvesting bananas at an early physiological age on susceptibility to $C$. musae. In both lowland and highland zones, harvesting bananas at an earlier physiological age (700 dd instead of $900 \mathrm{dd}$ ) reduced the susceptibility of bananas to $C$. musae and significantly increased their green life (Table 3), but there was a substantial concomitant decrease in fruit diameter in both zones and in finger length in the lowland zone in all experiments. These results also highlighted differences in the behavior of highland bananas as compared with those grown in lowland areas. At the same physiological age, fruit diameter and length were significantly greater in highland bananas. A highland banana that had accumulated 700 dd in 77 days of growth had almost the same diameter as a lowland banana that had accumulated $900 \mathrm{dd}$ in 78 days of growth. Highland bananas also had significantly lower susceptibility to anthracnose compared with lowland bananas. Lowland bananas harvested at 900 dd were significantly more susceptible to $C$. musae than highland bananas harvested at $900 \mathrm{dd}$ and lowland bananas harvested at $700 \mathrm{dd}$. These three groups were significantly more susceptible to

Table 2. Effect of flooding on the morphological characteristics, green life, and anthracnose susceptibility of bananas

\begin{tabular}{lccccc}
\hline & $\begin{array}{c}\text { FHP } \\
(\mathbf{d a y s})^{\mathbf{y}}\end{array}$ & $\begin{array}{c}\text { Fruit diam. } \\
(\mathbf{m m})\end{array}$ & $\begin{array}{c}\text { Finger length } \\
(\mathbf{c m})\end{array}$ & $\begin{array}{c}\text { Green life } \\
(\mathbf{d a y s})\end{array}$ & $\begin{array}{c}\text { Rotted area } \\
\left(\mathbf{m m}^{\mathbf{2}}\right)\end{array}$ \\
\hline Control & 70 & $31.2 \mathrm{a}^{\mathrm{z}}$ & $18.0 \mathrm{a}$ & $35.0 \mathrm{~ns}$ & $1,237 \mathrm{~ns}$ \\
Stress at flowering & 70 & $27.0 \mathrm{~b}$ & $15.2 \mathrm{~b}$ & $34.9 \mathrm{~ns}$ & $1,138 \mathrm{~ns}$ \\
Stress after 3.5 months & 70 & $28.4 \mathrm{~b}$ & $13.8 \mathrm{c}$ & $35.7 \mathrm{~ns}$ & $1,391 \mathrm{~ns}$ \\
$F$ value & - & 10.70 & 45.54 & 0.17 & 0.43 \\
Probability & - & $<0.01$ & $<0.01$ & 0.85 & 0.66 \\
\hline
\end{tabular}

y FHP = flowering-to-harvest period.

${ }^{\mathrm{z}}$ Means followed by the same letter are not statistically different according to the Newman-Keuls test $(P=0.05) . \mathrm{ns}=$ not significant. Eighteen fruits (from the third hand of the 9 bunches) contribute to each mean value.

C. musae than highland banana harvested at $700 \mathrm{dd}$.

Effects of the source-sink ratio on banana susceptibility to $C$. musae. Modifying the source-sink ratio by bunch trimming and defoliation had a marked effect on banana diameter and length in the three replicates of the experiment (Table 4). At physiological age $900 \mathrm{dd}$, the mean diameter of bananas from the treatment where the bunch was trimmed and fruits harvest at 900 dd was $8.7 \mathrm{~mm}$ greater than that of bananas from the treatment where the plant was defoliated and the fruits harvested at $900 \mathrm{dd}$. Bananas from the defoliated treatment and fruits harvested at diameter $34 \mathrm{~mm}$ took 24 days longer and consequently had accumulated a supplementary 320 dd compared with bananas from the treatment where the bunch was trimmed and the fruits harvested at the same diameter.

Modifications in the source-sink ratio had a highly significant effect on fruit susceptibility to $C$. musae and on the green life of bananas when harvested at a constant diameter $(34 \mathrm{~mm})$. Bananas from the treatment (Low $\mathrm{So} / \mathrm{Si}$ [diameter]) had a threefold greater rotted area in comparison with bananas from the treatment (High $\mathrm{So} / \mathrm{Si}$ [diameter]). Moreover, when bananas were harvested at $900 \mathrm{dd}$ irrespective of the diameter (31.1 to $39.8 \mathrm{~mm}$ ), no significant differences were noted with respect to rotted area and green life (Table 4).

\section{DISCUSSION}

The first experiment revealed that flooding had a marked impact on fruit diameter and length at harvest. Soil flooding is known to have effects on plant physiology, such as a reduction in root respiration (33), stomatal closure (31), a reduction in photosynthetic activity (32), and development of chlorosis (22). Stress also led to an increase in foliar Mn levels of $700 \mathrm{ppm}$ in leaves in the treatment "Stress after 3.5 months" and $244 \mathrm{ppm}$ in control plant leaves when measured at the flowering stage (data not shown). This clearly confirmed the known phenomenon whereby Mn uptake is high in plants growing in waterlogged anoxic soil as $\mathrm{Mn}$ is chemically reduced (15) and highly assimilated $(10,23)$.

Flooding stress of the root systems of plants is known to have an impact on the

Table 3. Morphological, physiological characteristics and anthracnose susceptibility of lowland and highland bananas

\begin{tabular}{lcccccc}
\hline & $\begin{array}{c}\text { FHP } \\
(\mathbf{d a y s})^{\mathbf{y}}\end{array}$ & $\begin{array}{c}\text { Temperature sum } \\
\mathbf{a c c u m u l a t i o n} \text { rate }(\mathbf{d d} / \mathbf{d a y})\end{array}$ & $\begin{array}{c}\text { Fruit diam. } \\
(\mathbf{m m})\end{array}$ & $\begin{array}{c}\text { Finger length } \\
(\mathbf{( m )})\end{array}$ & $\begin{array}{c}\text { Rotted area } \\
\left(\mathbf{m m}^{\mathbf{2}}\right)\end{array}$ & $\begin{array}{c}\text { Green life } \\
(\mathbf{d a y s})\end{array}$ \\
\hline Lowland 700 dd & 58 & 12.1 & $27.9 \mathrm{c}^{\mathrm{z}}$ & $12.9 \mathrm{~b}$ & $742.9 \mathrm{~b}$ & $41.3 \mathrm{a}$ \\
Lowland 900 dd & 78 & 11.5 & $32.0 \mathrm{~b}$ & $14.4 \mathrm{a}$ & $979.7 \mathrm{c}$ & $22.8 \mathrm{~b}$ \\
Highland 700 dd & 77 & 9.1 & $32.3 \mathrm{~b}$ & $15.9 \mathrm{a}$ & $333.8 \mathrm{a}$ & $41.4 \mathrm{a}$ \\
Highland 900 dd & 106 & -5.5 & $35.5 \mathrm{a}$ & $15.7 \mathrm{a}$ & $820.3 \mathrm{~b}$ & $22.4 \mathrm{~b}$ \\
$F$ value & - & - & 57.33 & 11.54 & $<.62$ & 226.13 \\
Probability & - & $-<0.01$ & $<0.01$ & $<0.01$ & $<0.01$ \\
\hline
\end{tabular}

\footnotetext{
${ }^{\text {y }} \mathrm{FHP}=$ flowering-to-harvest period.
}

${ }^{\mathrm{z}}$ Means followed by the same letter are not statistically different according to the Newman-Keuls test $(P=0.05)$. Twenty fruits (from the third hand of the 10 bunches) contribute to each mean value for each experiment. Data presented are combined from three experiments after testing for homogeneity of variance. 
aboveground parts (34), especially fruit growth, for example in kiwifruit (36). This reduction in fruit diameter and length at harvest in bananas is the result of a decrease in the fruit pulp filling rate and in cell multiplication $(20,21)$. Banana fingers from plants that have grown under anoxic soil conditions since the vegetative stage are shorter than those that have been subjected to anoxia from the flowering stage. Hence, stress can have a substantial impact on fruit size when it is applied at an early growth stage, especially during the cell division phase which begins a long time before the onset of flowering (24).

This marked effect on fruit morphology was not correlated with any physiological changes in susceptibility to $C$. musae. In addition, flooding of the soil had no effect on fruit green life. However a close relationship between the temperature sum accumulated by fruit during growth, its physiological age, and green life was observed. Regardless of their diameter, bananas were found to have the same green life when harvested at the same temperature sum.

Early harvesting of fruit, i.e., at physiological age 700 dd rather than $900 \mathrm{dd}$, reduced banana susceptibility to $C$. musae and increased the green life under the two soil-climate conditions tested. These experiments indicate that the physiological age of the fruit is a key factor in its susceptibility to C. musae. Our results, however, suggest that this is not the sole factor involved in this susceptibility, because at the same physiological age and thus the same green life, highland bananas were always significantly less susceptible than lowland bananas. It should be noted that temperature accumulation was faster in lowland zones than in the highlands. Our results showed that it took 106 days for highland bananas and 78 days for lowland bananas to accumulate $900 \mathrm{dd}$. Thus, the physiological development of lowland fruit was temporally faster. It is possible that accelerated development boosts its susceptibility to pathogens. For instance, bananas harvested in the greenhouse, which had also accumulated a 900 dd temperature sum very quickly (mean 70 days), were found to be highly susceptible to wound anthracnose.

Our results suggest that the susceptibility of bananas to wound anthracnose is closely linked with their physiological age based on temperature sums. However, the temperature sum accumulation rate also seems to be involved. Under the same soilclimate conditions, we found that only the physiological age was involved since the temperature conditions were identical for all bananas. A comparison of the susceptibility of bananas from two separate zones, with different temperature conditions, indicated that the temperature sum accumulation rate (temperature sum/number of days) was also a key factor (around 12 $\mathrm{dd} /$ day in lowland and $8.7 \mathrm{dd} /$ day in highland). In contrast, the green life seemed to be closely linked with the temperature sum. In lowland and highland areas, fruit harvest at a given physiological age resulted in the same fruit green life.

The effects of modifying the source-sink ratio on fruit morphology have already been studied through different degrees of bunch trimming, by shading the leaves to reduce photosynthesis, by defoliating plants or covering the bunches to increase fruit temperature $(5,12,17,19,21)$. Our present results agree with these studies on fruit morphology, and are original concerning fruit susceptibility to postharvest disease. Modifying the source-sink ratio clearly confirmed that the physiological age of bananas is a crucial factor in their susceptibility to $C$. musae. At the same physiological age, bananas from the same plot but of completely different diameters were found to have the same susceptibility and green life. Conversely, at the same diameter, bananas from the same plot sometimes had very different susceptibility levels, varying by one- to threefold, when the physiological ages of the bananas differed. Bananas that had accumulated the highest temperature sum were always the most susceptible to anthracnose. These results clearly confirmed the dissociation between fruit diameter and physiological age, and that the temperature sum is a valid indicator of the physiological development of bananas.

The results of the present experiments provide a partial explanation for common problems that are detrimental to the quality of bananas grown in lowland plantations during the rainy season, especially wound anthracnose and early ripening. Anoxic conditions can arise under such soilclimate conditions in conjunction with high rainfall and poor drainage. When this occurs, stressed banana plants undergo a slowdown in vegetative development, with a concomitant decline in the diameter growth rate of the fruit. The prevailing strategy is to harvest bananas once they have reached commercial diameter, irrespective of their physiological age. Then, such bananas have a short green life, an older physiological age, and are therefore highly susceptible to $C$. musae. These bananas are thus more susceptible to the development of wound anthracnose infection and to storage disorders associated with early ripening.

\section{LITERATURE CITED}

1. Berrill, F. W. 1956. Bunch cover for bananas. Queensl. Agric. J. 82:435-440.

2. Chillet, M., and de Lapeyre de Bellaire, L. 1996. Elaboration de la qualité de la banane. Détermination de critères de mesure. Fruits 51:317-326.

3. Chillet, M., and de Lapeyre de Bellaire, L. 2002. Variability in the production of wound ethylene in bananas from the French West Indies. Sci. Hortic. 96:127-137.

4. Chillet, M., de Lapeyre de Bellaire, L., Dorel, M., Joas, J., Dubois, C., Marchal, J., and Perrier, X. 2000. Evidence for the variation in susceptibility of bananas to wound anthracnose due to Colletotrichum musae and the influence of edaphic conditions. Sci. Hortic. 86:33-47.

5. Daniells, J., Lisle, A., and Bryde, N. 1994 Effect of bunch trimming and leaf removal at flowering on maturity bronzing, yield, and other aspects of fruit quality of bananas in North Queensland. Aust. J. Exp. Agric. 34:259-265.

6. Daniells, J., O'Farrell, P., Mulder, J., and Campbell, S. 1987. Effects of bunch covering and bunch trimming on bananas in North Queensland. Queensl. J. Agric. Anim. Sci. 44:101-105.

7. De Lapeyre de Bellaire, L. 1999. Bioécologie de Colletotrichum musae (Berck. \& Curt.) Arx, agent de l'anthracnose des bananes, dans les

Table 4. Effects of modifying the source-sink ratio on physiological characteristics of fruits

\begin{tabular}{|c|c|c|c|c|c|c|c|}
\hline Treatment $^{\mathrm{x}}$ & $\begin{array}{l}\text { Harvest } \\
\text { criteria }^{y}\end{array}$ & $\begin{array}{c}\text { Flowering-to-harvest } \\
\text { period (days) }\end{array}$ & $\begin{array}{l}\text { Physiological } \\
\text { age (in dd) }\end{array}$ & $\begin{array}{l}\text { Fruit diameter } \\
\qquad(\mathrm{mm})\end{array}$ & $\begin{array}{c}\text { Finger length } \\
(\mathrm{cm})\end{array}$ & $\begin{array}{l}\text { Green life } \\
\text { (days) }\end{array}$ & $\begin{array}{l}\text { Rotted area } \\
\quad\left(\mathbf{m m}^{2}\right)\end{array}$ \\
\hline \multirow[t]{2}{*}{ FR } & $\mathrm{dd}$ & 73 & 898 & $39.8 \mathrm{a}^{\mathrm{z}}$ & $20.1 \mathrm{a}$ & $25.7 \mathrm{~b}$ & $1,245 \mathrm{~b}$ \\
\hline & FD & 63 & 746 & $34.9 \mathrm{~b}$ & $18.8 \mathrm{~b}$ & $37.3 \mathrm{a}$ & $693 \mathrm{c}$ \\
\hline \multirow[t]{2}{*}{$\mathrm{D}$} & $\mathrm{dd}$ & 73 & 898 & $31.1 \mathrm{c}$ & $14.6 \mathrm{~d}$ & $22.7 \mathrm{~b}$ & $1,557 \mathrm{~b}$ \\
\hline & FD & 87 & 1,066 & $34.0 \mathrm{~b}$ & $15.7 \mathrm{~cd}$ & $12.7 \mathrm{c}$ & $2,057 \mathrm{a}$ \\
\hline \multirow[t]{2}{*}{$\mathrm{C}$} & dd & 73 & 898 & $34.9 \mathrm{~b}$ & $17.3 \mathrm{c}$ & $25.6 \mathrm{~b}$ & $1,286 \mathrm{~b}$ \\
\hline & FD & 72 & 887 & $34.5 \mathrm{~b}$ & $17.0 \mathrm{c}$ & $24.0 \mathrm{~b}$ & $1,313 \mathrm{~b}$ \\
\hline$F$ value & & - & - & 7.93 & 16.65 & 5.87 & 12.37 \\
\hline Probability & & - & - & $<0.01$ & $<0.01$ & $<0.01$ & $<0.01$ \\
\hline
\end{tabular}

${ }^{x} \mathrm{FR}=$ fruit removal, $\mathrm{D}=$ defoliation, $\mathrm{C}=$ control

${ }^{\mathrm{y}} \mathrm{dd}=$ degree-days, $\mathrm{FD}=$ fruit diameter.

${ }^{\mathrm{z}}$ Means followed by the same letter are not statistically different according to the Newman-Keuls test $(P=0.05)$. Twenty fruits (from the third hand of the 10 bunches) contribute to each mean value for each experiment. Data presented are combined from three experiments after testing for homogeneity of variance. 
conditions tropicales humides de la Guadeloupe. Ph.D. diss. Paris XI, Orsay (France).

8. De Lapeyre de Bellaire, L., Chillet, M., Dubois, C., and Mourichon, X. 2000. Importance of different source of inoculum and dispersal methods of conidia of Colletotrichum musae, the causal agent of banana anthracnose, for fruit contamination. Plant Pathol. 49:782-790.

9. De Lapeyre de Bellaire, L., and Mourichon, X. 1997. The pattern of fungal contamination of the banana bunch during its development and potential influence of incidence of crown-rot and anthracnose diseases. Plant Pathol. 46:481-489.

10. Dorel, M. 1993. Développement du bananier dans un andosol de Guadeloupe: Effet de la compacité du sol. Fruits 48:83-88.

11. FAO, ISRIC, and ISSS. 1998. Word Reference Base for Soil Resources: Keys to reference soils groups of the World. World Soil Resources Report. 84. FAO, Rome.

12. Ganry, J. 1975. Influence du gainage des régimes de bananier avec une housse de polyéthylène sur la température des fruits dans les conditions de Neufchâteau (Guadeloupe). Fruits 30:735-738.

13. Ganry, J. 1978. Recherche d'une méthode d'estimation de la date de récolte du bananier à partir des données climatiques dans les conditions des Antilles. Fruits 33:669-680.

14. Ganry, J., and Meyer, J. P. 1975. Recherche d'une loi d'action de la température sur la croissance des fruits du bananier. Fruits 30:375-392.

15. Gotoh, S., and Patrick, W. H., Jr. 1972. Transformation of manganese in a waterlogged soil as affected by redox potential and $\mathrm{pH}$. Proc. Am. Soc. Soil Sci. 36:738-742.

16. Hostachy, B., Vegh, I., Leroux, P., Jacquemot, E., Foucher, S., and Pigou, R. 1990. Bananes de la Martinique. Incidence des problèmes fongiques sur la qualité. Phytoma 420:37-44.

17. Jannoyer, M., and Chillet, M. 1998. Amélioration de la croissance des bananes par utilisation de la gaine Katryx. Fruits 53:219-228.

18. Jenny, C., Carreel, F., Tomekpe, K., Perrier, X., Dubois, C., Horry, J. P., and Tezenas du montcel, H. 1999. Banana. Pages 99-124 in: Genetic Diversity of Cultivated Tropical Plants. P. Hamon, M. Seguin, X. Perrier, and J. C. Glaszmann, eds. CIRAD, Paris.

19. Johns, G. 1996. Effects of bunch trimming and double bunch covering on yield of bananas during winter in New South Wales. Aust. J. Exp. Agric. 36:229-235.

20. Jullien, A., Malézieux, E., Michaux-Ferrière, N., Chillet, M., and Ney, B. 2001. Withinbunch variability in banana Fruit Weight: Importance of developmental lag between fruits. Ann. Bot. 87:101-108.

21. Jullien, A., Munier-Jolain, N. G., Malézieux, E., Chillet, M., and Ney, B. 2001. Effect of pulp cell number and assimilate availability on dry matter accumulation rate in a banana fruit (Musa sp. AAA group 'Grande Naine' (Cavendish subgroup)). Ann. Bot. 88:321-330.

22. Kramer, P. J. 1951. Causes of injury to plants resulting from flooding of the soil. Plant Physiol. 26:722-736.

23. Larson, K. D., Schaffer, B., and Davies, F. S. 1992. Flooding, mineral nutrition and gas exchange of mango trees. Sci. Hortic. 52:113-124.

24. Lassoudière, A., and Maubert, P. 1971. Evolution des dimensions des bananes entre l'émission de l'inflorescence et la récolte du régime. Fruits 26:321-331.

25. Liu, F. W. 1976. Banana response to low concentrations of ethylene. J. Am. Soc. Hortic. Sci. 101:222-224.

26. Meredith, D. S. 1960. Studies on Gloeosporium musarum Cke. \& Massee causing storage rots of Jamaican bananas. Ann. Appl.
Biol. 48:518-528.

27. Mondal, A. H., and Parbery, D. G. 1992. The spore matrix and germination in Colletotrichum musae. Mycol. Res. 96:592-596.

28. Muirhead, I. F., and Deverall, B. J. 1981. Role of appressoria in latent infection of banan fruits by Colletotrichum musae. Physiol. Plant Pathol. 19:77-84

29. Peacock, B. 1973. Effect of Colletotrichum musae infection on the preclimacteric life of banana. Queensl. J. Agric. Anim. Sci. 30:239-246.

30. Peacock, B and Blake, J. R 1970. Some effects of non-damaging temperatures on the life and respiratory behaviour of bananas. Queensl. J. Agric. Anim. Sci. 27:147-168.

31. Pezeshki, S. R. 1994. Plant response to flooding. Pages 289-321 in: Plant-Environment Interactions. R. E. Wilkinson, ed. Marcel Decker, New York.

32. Pezeshki, S. R., and Chambers, J. L. 1985 Responses of cherrybark oak seedlings to short-term flooding. For. Sci. 31:760-771.

33. Pradet, A., and Raymond, P. 1983. Adenine nucleotide ratios and adenylate energy charge in energy metabolism. Annu. Rev. Plant Physiol. 34:199-224.

34. Schaffer, B. 1998. Flooding response and water-use efficiency of subtropical and tropical fruit trees in an environmentally-sensitive wetland. Ann. Bot. 81:475-481.

35. Sela-Buurlage, M. B., Epstein, L., and Rodriguez, R. J. 1991. Adhesion of ungerminated Colletotrichum musae conidia. Physiol. Mol. Plant Pathol. 39:345-352.

36. Smith, G. S., and Miller, S. A. 1991. Effects of root anoxia on the physiology of kiwifruit vines. Acta Hortic. 297:401-408.

37. Swinburne, T. R., and Brown, A. E. 1983 Appressoria development and quiescent infections of banana fruit by Colletotrichum musae. Trans. Br. Mycol. Soc. 80:176-178. 